\title{
Intermittent water deficit in soil and micromorphology of the Ora-pro-nóbis leaf epidermis
}

\begin{abstract}
The amount of epidermal and stomatal cells in the leaves, stomatal density and stomatal index, can be modified under the influence of abiotic stresses. This study aimed to quantify the epidermal and stomatal cells on leaves of Ora-pro-nóbis plants (Pereskia aculeata Mill.) subjected to growing intermittent water deficits in soil. Plants were grown in pots inside a greenhouse with intermittent variation of matric potential (MP) in the soil, in a completely randomized experiment with six replications and two plants per experimental unit, one plant per pot. The treatments consisted in adding to the pots a volume of water, calculated with basis on the water retention curve, to raise the matric potential to $-5 \mathrm{kPa}$ whenever the mean substrate matric potential reached values around $-10 \mathrm{kPa},-30 \mathrm{kPa},-50 \mathrm{kPa}$, and $-70 \mathrm{kPa}$. After 130 days of transplant, two sun-exposed leaves and two leaves of the region shaded by other leaves were selected from each plant, in position between 60 and $100 \mathrm{~cm}$ from the base of a budding cutting. Manual cuts were made, parallel to the adaxial and abaxial leaf surface, in the middle region of the leaf, which were washed with $70 \%$ ethanol and stained with $1 \%$ safranin. The images were obtained using a binocular optical micro scope with magnification of 400 times and captured by camera. We found that reducing intermittent matric potential on the substrate from $-5 \mathrm{kPa}$ to $-70 \mathrm{kPa}$ resulted in micromorphological changes in leaf epidermis due to the increase in the number of epidermal cells and decreased stomatal index on the adaxial side, but does not result in variation the number of stomatal cells and stomatal density on both faces of the leaves plant.Such modifications can explain the pro-nobis adaptation to water deficit conditions in the root zone.
\end{abstract}

Volume 4 Issue 6 - 2020

\author{
Carla Regina Amorim dos Anjos Queiroz,' \\ Nágilla Daliane Feliciano,' Reginaldo \\ Rodrigues De Andrade,' Sérgio Antônio \\ Lemos De Morais, ${ }^{2}$ Luiz Carlos Pavani ${ }^{3}$ \\ 'PhD Professor in Agronomy, Soil Science, Takes classes in \\ Chemistry and Organic Chemistry for the Food Technology \\ course - IFTM, Brazil \\ ${ }^{2}$ Instituto de Química, Universidade Federal de Uberlândia \\ (UFU), Brazil \\ ${ }^{3}$ Engenharia Rural, Sao Paulo State University (UNESP), Brazil
}

Correspondence: Carla Regina Amorim dos Anjos Queiroz, PhD Professor in Agronomy, Instituto Federal de Educação, Ciência e Tecnologia do Triângulo Mineiro (IFTM), Brazil, Email carlaregina@iftm.edu.br

Received: October 24, 2020 | Published: December 03, 2020

Keywords: abiotic stress, irrigation, Pereskia aculeata, stomatic cells, unconventional vegetable

\section{Introduction}

Ora-pro-nóbis (OPN) (Pereskia aculeata Mill.) is a cactus with true leaves ${ }^{1}$ that in Brazil is traditionally used in some regions as unconventional vegetable in natura $a^{2,3}$ or after processing. ${ }^{4-6}$ Its consumption increases the use of native Brazilian species, since it can be found naturally from south (Rio Grande do Sul state) to north regions (Maranhão state), in the Atlantic Forest, Cerrado and Caatinga biome. ${ }^{7}$ Being a native species showing potential to become an agricultural crop, ${ }^{8,9}$ it is important to know the morphological variations that it may present in conditions of environmental restrictions, such as intermittent and systematic variation in soil water deficit. This happens, for example, between intervals of rainfall in the more humid seasons or in the drier ones when using irrigation techniques.

Plants subjected to water deficit may have different anatomical and/ or physiological changes such as thickening of the cuticle, reduction in leaf area and plant height, changing the mass ratio between root and shoot, stomatal closure and inhibition of new leaves emissions. ${ }^{10}$

In leaves, gas exchange of water and carbon dioxide are made through the stomata, allowing plants to accumulate carbon and control the water loss enabling its existence in locations with environmental variations. ${ }^{11}$ On both leaf sides, adaxial and abaxial, the stomata may show different responses when the species of plants are subjected to water stress condition, from very insensitive even to moderate stress to very sensitive even to small water changes. ${ }^{12}$

The growing conditions, such as control of water availability in the root zone, fertilization and cultural practices, may alter the anatomy of plants. ${ }^{13}$ This can be evaluated by quantifying the stomatal and epidermal cells of the leaves and the relationship between these cells, besides serving for anatomical characterization of the species, as done by Sajeva and Mauseth ${ }^{14}$ in the Pereskioideae and Cactoideae cacti subfamilies and by Garcia et al..$^{15}$ in plants of the genus Pereskia (P. aculeata, P. bleo, P. guamacho and P. ziniiflora) and without culture condition previously known. Thus, changes in the soil water availability may result in variation in the stomatal density as an indirect effect of the expansion and size of the epidermal cells of leaves. ${ }^{16}$

The variation of the soil water status, which may cause water stress to the plant, can be characterized by evaluating the matric potential in one or several points of the soil-plant system when in conditions of no water saturation and no ambient salinity. ${ }^{17}$ The soil matric potential can be more readily determined using the technique of in situ tension meter, ${ }^{18}$ using microporous cup tensiometers in the potential interval between 0 and $-80 \mathrm{kPa}^{17}$

Considering the limited knowledge of physiology and agronomic management of Ora-pro-nóbis, we evaluate at the level of the leaf epidermal cells the response of this plant to increasing water deficits between $-5 \mathrm{kPa}$ and $-70 \mathrm{kPa}$ of soil matric potential.

\section{Material and methods}

The experiment was conducted in Uberlândia, Minas Gerais, Brazil (altitude $633 \mathrm{~m}$, latitude $18^{\circ} 45^{\prime} \mathrm{S}$ and longitude $48^{\circ} 17^{\prime} \mathrm{W}$ ) from seedlings produced from selected cuttings $(20 \mathrm{~cm}$ in length and diameter between 8 and $9 \mathrm{~mm}$ ) from the same mother plant and 
planted in containers filled with $1 \mathrm{dm}^{3}$ of a commercial substrate. The selected seedlings (48) were transplanted to pots containing $10.5 \mathrm{dm}^{3}$ of substrate prepared with a mixture of soil taken from 0 to $20 \mathrm{~cm}$ depth of a typical dark red latosol, medium river sand and cow manure, in the ratio of $6: 3: 1$ by volume.

The substrate with lime (base saturation to $70 \%$ ), $50 \mathrm{~g}$ of commercial granular fertilizer, formula 4:14:8 $\left(\mathrm{N}_{2}: \mathrm{P}_{2} \mathrm{O}_{5}: \mathrm{K}_{2} \mathrm{O}\right)$ and $3950 \mathrm{~mL}$ of water per pot, a value pre determined in 3 pots, from which the drainage of excess water was started. The substrate showed $\mathrm{pH} 6.6 ; \mathrm{H}+\mathrm{Al}=2.3 \mathrm{cmol} \mathrm{dm}^{-3} ; \mathrm{Mg}=1.2 \mathrm{cmol} \mathrm{dm}^{-3} ; \mathrm{Ca} 3.3 \mathrm{cmol} \mathrm{dm}^{-3}$; $\mathrm{P}$ and $\mathrm{K}=6.6$ and $430 \mathrm{mgdm}^{-3}$, respectively. The cation exchange capacity was of 5.6; aluminum saturation of $0 \%$ and the percentage of organic matter was of 2.6. The substrate had a density of $1.28 \mathrm{~kg} \mathrm{dm}^{-3}$, $440 \mathrm{~g} \mathrm{~kg}^{-1}$ of clay, $91 \mathrm{~g} \mathrm{~kg}^{-1}$ of silt, $423 \mathrm{~g} \mathrm{~kg}^{-1}$ of coarses and $45 \mathrm{~g} \mathrm{~kg}^{-1}$ of fine sand.

The pots were placed on a bench in a green house (covered on one side with plastic $150 \mu \mathrm{m}$ thick and the other sides with shaded screen at $50 \%$ ). The plants were submitted, 20 days after transplanting, for 110 days, to four average lower limits of matric potential (MP) in the soil $(-10 \mathrm{kPa},-30 \mathrm{kPa},-50 \mathrm{kPa}$ and $-70 \mathrm{kPa})$. The experimental design was a completely randomized with six replications and two plants per experimental unit, with one plant per pot.

For each MP treatment, during each irrigation, it was applied a volume of water calculated to raise the MP of the substrate to the upper level of $-5 \mathrm{kPa}$ ("pot capacity").

The control of the intermittency on irrigation was done by the MP of each treatment, which was calculated as the average of three readings per day, in three different tensiometers.

In each irrigation all pots of each treatment were irrigated with a calculated amount of water to raise the MP from the lower limit of the treatment (water content $-\theta, \mathrm{m}^{3} \mathrm{~m}^{-3}$ : for $-10 \mathrm{kPa}, \theta=0.231$; for -30 $\mathrm{kPa}, \theta=0.241$; for $-50 \mathrm{kPa}, \theta=0.233$ and for $-70 \mathrm{kPa}, \theta=0.292$ ) until $-5 \mathrm{kPa}$ ("pot capacity", $\theta=0.375 \mathrm{~m}^{3} \mathrm{~m}^{-3}$ ), considering the volume of substrate in the pot of $0.0105 \mathrm{~m}^{3}$ ). The volumetric moisture content for each of the points of MP was estimated through Genuchten model ${ }^{19}$ whose coefficients were obtained according to the methodology of Dourado Neto et al..$^{20}$

After 130 days of transplant, two sun-exposed leaves and two leaves of the region shaded by other leaves were selected from each plant, in position between 60 and $100 \mathrm{~cm}$ from the base of a budding cutting.

The leaves were stored inplastic bags, kept refrigerated at (5 to $10^{\circ} \mathrm{C}$ ) and then analyzed. Manual cuts were made with stain less steel blade, parallel to the adaxial and abaxial leaf surface, in the middle region of the leaf, which were washed with $70 \%$ ethanol and stained with $1 \%$ safranin.

The images were obtained using a binocular optical microscope with magnification of 400 times and captured by camera. Two photographs of different visual fields were recorded on each surface. The numbers of stomatal cells (STC) and epidermal cells (EPIC) were determined in the abaxial and adaxial leaves using the free program Anati Quanti. ${ }^{21}$

Subsequently, we determined the stomatal index (SI) [(STC/(STC + EPIC))100] and the stomatal density (SD) (STC/visual field area), according to Aguiar et al. ${ }^{21}$ and the ratios between the EPIC (EPICR), the STC (STCR) and between SI (SIR) of the adaxial and abaxial surfaces.

The results were submitted to analysis of variance by $\mathrm{F}$ test at $5 \%$ and $1 \%$ probability. The averages between the adaxial and abaxial surfaces were compared by Tukey test at $5 \%$ probability and the effects of MP treatments were evaluated by polynomial regression analysis to grade 2 , at $1 \%$ and $5 \%$ probability, aimed at biological interpretation of responses.

\section{Results and discussion}

In this work the intermittence is considered to be the frequency at which the condition of better water comfort in the soil for the plant was recovered by irrigation. The water comfort of the plant is greater the closer the root zone of the plant is maintained to the upper limit of available water in the substrate.

In this experiment, the upper limit of available water corresponded to the volumetric water content retained in the substrate to $-5 \mathrm{kPa}$ MP. Thus, each treatment of lower limit of MP resulted in frequencies of water application in the pots, or distinct intermittences. A lower intermittence indicates that the plants were irrigated at a lower frequency, and thus were longer subjected to conditions of lower water comfort in the root zone.

Thus, during the 110 days of treatment application, plants subjected to variations of the MP in the root zone from $-5 \mathrm{kPa}$ as the upper limit of the MP substrate, became subjected to the following conditions: $10 \mathrm{kPa}$ : were irrigated with average frequency of two days, received 55 irrigations and $51.2 \mathrm{~L}$ of water per pot; $-30 \mathrm{kPa}$ : the average frequency of irrigation was of 4 days, resulting in 28 irrigations and $35.5 \mathrm{~L}$ of water per pot; $-50 \mathrm{kPa}$ : average frequency of 5 days, 22 irrigations and $30.5 \mathrm{~L}$ per pot; $-70 \mathrm{kPa}$ : average frequency of 8 days, 14 irrigations and $20.4 \mathrm{~L}$ of water per pot.

However, despite these differences of intermittency and intensity of water deficit in the root zone, the leaves of OPN under these conditions, maintained the same micro morphological characteristics already reported by Sajeva and Mauseth, ${ }^{14}$ Garcia et al. ${ }^{15}$ and Rhizopoulou and Psaras ${ }^{22}$ for Pereskia aculeata, although these authors did not specify the conditions of climate and soil to what the plants were submitted.

That is, regardless of the MP applied, OPN plants showed leaves with stomata on the abaxial and adaxial surfaces (amphistomatic) in the same way as SD, SI, number of epidermal cells and significantly higher stomatal cells on the abaxial surface than on the adaxial surface of the leaves $(\mathrm{p}<0.05$; Table 1$)$.

According to Rhizopoulou and Psaras ${ }^{22}$ the difference both in density and SI among leaf surfaces is not unexpected, as perfect amphistomatic leaves are rare. However, Eggli ${ }^{23}$ reported nearly equal amounts of stomata on leaf surfaces of some species of the genus Pereskia, for example, in Pereskia diaz-romeroana and Pereskia zinniiflora.

The results of stomatal density (SD) obtained for all treatments in this study, are in the range reported in leaves of plants of the genus Pereskia, 8 species, ranging from $16.3 \pm 0.9$ to $99.6 \pm 3.2$ stomata $\mathrm{mm}^{-2}$ on the bottom surface, and of 0.0 to $98.3 \pm 3.2$ stomata $\mathrm{mm}^{-2}$ on the upper surface. ${ }^{25,14}$ 
Table I Averages \pm standard deviation of the quantity of epidermal cells (EPIC) and stomatal cells (STC), the stomatal index (SI) and stomatal density (SD), in leaves of Ora-pro-nóbis, at 130 days after transplanting, depending on the matric potential in the substrate (MP)

\begin{tabular}{|c|c|c|c|c|c|c|}
\hline \multirow{2}{*}{$\begin{array}{l}\text { Leaf } \\
\text { surface }\end{array}$} & \multicolumn{5}{|c|}{ Matric potential $(\mathrm{kPa})$} & \multirow[t]{2}{*}{ CV (\%) } \\
\hline & -10 & -30 & -50 & -70 & (2)Average & \\
\hline \multicolumn{7}{|c|}{ (I) Quantity of epidermic cells (EPIC) } \\
\hline Adaxial & $152,6 \pm 14,8$ & $164,4 \pm 8,8$ & $157,6 \pm 4,0$ & $181,3 \pm 13,2$ & $163,8 \pm 10,2 B$ & 3,8 \\
\hline Abaxial & $279,7 \pm 29,3$ & $282,2 \pm 20,8$ & $259,0 \pm 17,0$ & $295,1 \pm 21,7$ & $278,9 \pm 22,2 \mathrm{~A}$ & \\
\hline \multicolumn{7}{|c|}{ (1) Quantity of stomatic cells (STC) } \\
\hline Adaxial & $6, I \pm 0,8$ & $6,0 \pm 0,7$ & $5,7 \pm 0,6$ & $6,2 \pm 0,5$ & $6,0 \pm 0,7 \mathrm{~B}$ & 6,2 \\
\hline Abaxial & $14,0 \pm 2,3$ & $13,9 \pm 1,3$ & $13,2 \pm 1,7$ & $14,5 \pm 1,6$ & $13,9 \pm 1,7 \mathrm{~A}$ & \\
\hline \multicolumn{7}{|c|}{ (1) Stomatic index (SI, \%) } \\
\hline Adaxial & $3,8 \pm 0,3$ & $3,8 \pm 0,4$ & $3,5 \pm 0,4$ & $3,3 \pm 0,2$ & $3,5 \pm 0,3 \mathrm{~B}$ & 9,7 \\
\hline Abaxial & $4,8 \pm 0,6$ & $4,7 \pm 0,4$ & $4,9 \pm 0,4$ & $4,7 \pm 0,2$ & $4,7 \pm 0,4 \mathrm{~A}$ & \\
\hline \multicolumn{7}{|c|}{ (1) Stomatal density (SD, stomata $\mathrm{mm}^{-2}$ ) } \\
\hline Adaxial & $38,2 \pm 4,9$ & $37,6 \pm 4,1$ & $36,0 \pm 4,0$ & $38,8 \pm 3,1$ & $37,7 \pm 4,0 \mathrm{~B}$ & 13,2 \\
\hline Abaxial & $87,5 \pm 14,4$ & $87,2 \pm 8,2$ & $82,8 \pm 10,3$ & $91,3 \pm 9,9$ & $87,2 \pm 10,7 \mathrm{~A}$ & \\
\hline
\end{tabular}

(I) Original unprocessed data. The statistical analysis was performed with the original data processed to $\sqrt{\mathrm{x}}$;

${ }^{(2)}$ Capital letters compare averages between the adaxial and abaxial surfaces of leaves in each variable, by Tukey test at $5 \%$ probability; CV -coefficient of variation

Sajeva and Mauseth ${ }^{14}$ determined that the SD for leaves of P.aculeata is significantly lower in the epidermis of the adaxial surface $\left(23.2 \pm 1.9\right.$ stomata $\left.\mathrm{mm}^{-2}\right)$ than on the abaxial surface $\left(58.6 \pm 2.9\right.$ stomata $\left.\mathrm{mm}^{-2}\right)$, values which are smaller than those obtained in this research, which may be related to different conditions of soil type, climate variables and soil water regime. On the adaxial surface, discrepant values cited here were found by Garcia et al. ${ }^{15}$

These authors found on the adaxial surface of the leaves of P.aculeata plant under the sun SD and SI values much smaller ( 0.8 stomata $\mathrm{mm}^{-2}$ and $0.1 \%$, respectively) than those reported here. However, on the abaxial surface values of SD (91.6 stomata $\mathrm{mm}^{-2}$ ) and SI $(9.6 \%)$ were more consistent with those obtained in this work (87.2 stomata $\mathrm{mm}^{-2}$ and $4.7 \%$, respectively).

Data obtained on the abaxial surface are considered more reliable than the ones in the adaxial surface, ${ }^{15}$ possibly due to less interference from environmental factors such a slight incidence, since other factors such as water availability and atmospheric $\mathrm{CO}_{2}$ content do not differ on leaf surfaces. This fact explains the observations in the data from SD on the abaxial surface in this work and in the works of Sajeva and Mauseth $^{14}$ and Garcia et al. ${ }^{15}$

The smaller number and smaller density of stomata on the adaxial surface may be justified in order to minimize water loss, because the higher incidence of sunlight on this surface makes it potentially subjected to increased sweating. Yet SI is a microm or phometric parameter considered independent of the ambient in which plants grow and thus has greater value than the $\mathrm{SD}$ as a taxonomic tool Garcia et al. ${ }^{15}$ except for extreme conditions. ${ }^{16}$

On both sides of the leaves the number of stomatal cells and SD were not affected $(p>0.05)$ by varying water conditions in the root zone of the plants due to the variation of the MP on the substrate (Figure 1). The density of stomata is more sensitive to environmental changes and plant species; under water deficit there are plants that respond with an increase in SD and in others it is not altered ${ }^{12}$ as observed for OPN in the range of MP applied in this work.

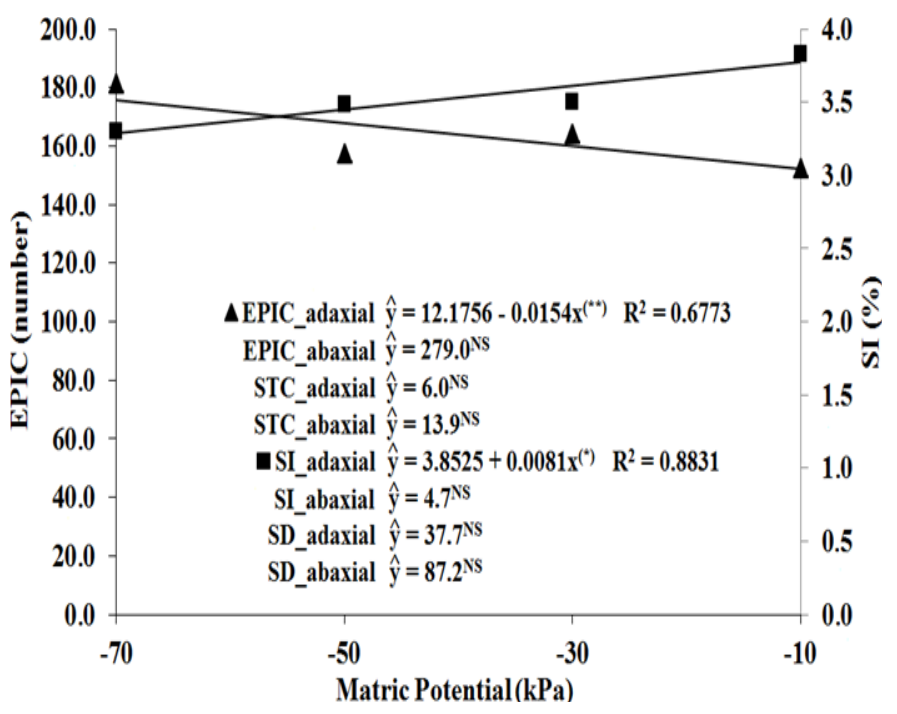

Figure I Changes in quantity of epidermal cells (EPIC) and stomatal cells (STC) of stomatal index (SI) and stomatal density (SD) in the adaxial and abaxial surfaces of Ora-pro-nóbis leaves, at 130 days after transplanting due to substrate matric potential. ( ${ }^{N},{ }^{*},{ }^{*}$ ) not significant, significant at 5 and $1 \%$ probability by $\mathrm{F}$ test, respectively.

This may be an indication that the studied species is naturally tolerant to water deficit, with efficient use of available water, ${ }^{25,26}$ since the stomata are cells strongly influenced by conditions prevailing in the habitat of the plant ${ }^{27}$ and if these cells that are responsible for maintaining the movement of ground water to the leaves ${ }^{11}$ remained unchanged in the number of units per $\mathrm{mm}^{-2}$ in the range of soil water deficit, they also contributed to the tolerance of the plant to the reduction in water availability in the soil. 
The number of epidermal cells and stomatal index be have differently among the leaves surfaces. On the abaxial surface there was no difference in the values of these variables $(p>0.05)$, while on the adaxial surface the number of epidermal cells increased linearly with the reduction of MP from $-10 \mathrm{kPa}$ to $-70 \mathrm{kPa}(\mathrm{p}<0.01)$ and SI decreased also with linear tendency $(\mathrm{p}<0.05)$. This result points to the occurrence of reduction in the size of epidermal cells in this surface, since there was no change in the number of stomata (Figure 1). The reduction in the cell size is a mechanism of anatomic modification favorable to lower osmotic potential and consequent maintenance of cell turgor, which is required for expansion of the plant cell. ${ }^{28,29}$

These results indicate that for Pereskia aculeata Mill. the epidermal cells are more sensitive than the stomatal cells, and that the adaxial surface eof the leaf is more sensitive than the abaxial surface to intermittent variation of MP in the root zone.

The EPICR linearly increased with the reduction of MP (increasing water deficit in the substrate) $(p<0.01$, Figure 2$)$, due to the linear increase of the epidermal cells on the adaxial surface and to no variation of these on the abaxial surface as well (Figure 1).

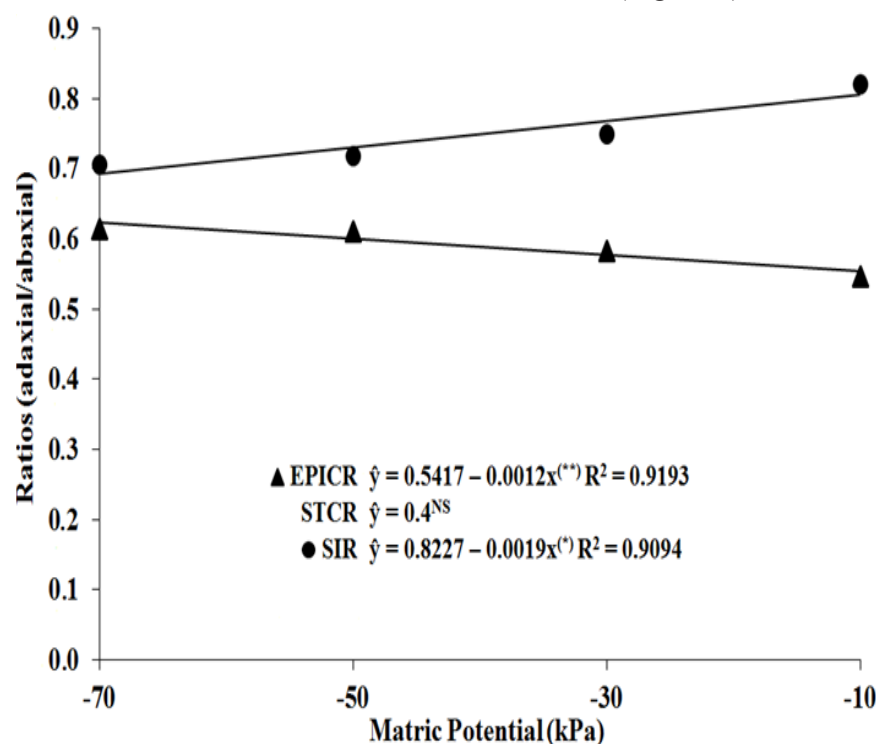

Figure 2 Adaxial/abaxial ratios among epidermal cells (EPICR), stomatal cells (STCR) and stomatal index (SIR) of leaves of Ora-pro-nóbis, at I 30 days after transplanting, due to to substrate matric potential. $\left(\mathrm{NS}^{*},{ }^{* *}\right)$ not significant, significant at 5 and I\% probability by $\mathrm{F}$ test, respectively.

Where as there was no significant variation on the leaf area of plants due to the variation in MP on the substrate $(p>0.05$, data not shown),${ }^{30}$ this increase means that probably there was a reduction in the size of epidermal cells in the adaxial surface of the leaves. This reduction can be considered as a factor favoring for resistance to water deficit, because in severe drought conditions the epidermal and mesophilic cells of smaller size are more resistant to break down than those of larger size. ${ }^{28,29}$

The SDR was unchanged by reducing the MP, indicating that in both leaf surfaces the number of stomata per $\mathrm{mm}^{-2}$ was kept equal over the range of MP studied. SIR linearly decreased $(p<0.05)$ with the reduction of MP, due to the reduction in SI of the adaxial surface (Figure 2).

\section{Conclusion}

In the intermittency interval to water deficit in the root zone from $-5 \mathrm{kPa}$ to $-70 \mathrm{kPa}$ for the matric potential, the morphology of the epidermis of the leaves of Ora-pro-nóbis is changed only in the adaxial and just due to the reduction in the number of epidermal cells in this leaf side, not occurring quantitative change of stomatal cells of the adaxial and abaxial surfaces. Such modifications can justify the wide range of avaiable water conditions in the root zone that the Orapro-nóbis is able to be growth.

\section{Acknowledgments}

The authors thank Instituto Federal do Triângulo Mineiro.

\section{Conflicts of interest}

Authors declare no conflict of interest exists.

\section{References}

1. Duarte MR, Hayashi SS. Estudo anatômico de folha e caule de Pereskia aculeata Mill. (Cactaceae). Revista Brasileira de Farmacognósia [online]. 2005;15(2):103-109.

2. BRASIL. Ministério da agricultura pecuária e abastecimento. Manual de hortaliças não-convencionais. Diário Oficial da República Federativa do Brasil. Belo Horizonte, 2010. Consultado em [2011-01-15].

3. BRASIL. Ministério da saúde. secretaria de atenção à saúde. departamento de atenção básica.alimentos regionais brasileiros[online]/ ministério da saúde, secretaria de atenção à saúde, departamento de atenção básica. 2nd ed. Brasília: Ministério da Saúde, 2015.484

4. Almeida MEF, Corrêa AD. Utilização de cactáceas do gênero Pereskia na alimentação humana em um município de Minas Gerais. Ciência Rural [online]. 2012;42(4):751-756

5. Amaral TN, Junqueira LA, Prado MET. Blends of Pereskia aculeata Miller mucilage, guar gum, and gum Arabic added to fermented milk beverages. Food Hydrocolloids [online]. 2018;79:331-342.

6. Sato R, Cilli LPL, Oliveira BE, et al. Nutritional improvement of pasta with Pereskia aculeata Miller: a non-conventional edible vegetable. Food Science and Technology[online], Campinas,. 2019;39(1):28-34.

7. Zappi D, Taylor N. Cactaceae in Flora do Brasil 2020 em construção [online]. Jardim Botânico do Rio de Janeiro.consultado em 2020.

8. Madeira, NR, Botrel N, Amaro GB, et al. B. da. Pereskia aculeata: orapro-nóbis. In: Coradin L, Camillo J, editors. Espécies nativas da flora brasileira de valor econômico atual ou potencial: plantas para o futuro: região Nordeste. Brasília, DF: MMA, 2018.

9. Telles CC, Matos JMM, Madeira NR, et al. da. Pereskia aculeata: orapro-nóbis. In: Fontes VR, Camillo J, editors. Espécies nativas da flora brasileira devalor econômico atual ou potencial: plantas para o futuro: região Centro-Oeste. Brasília, DF: MMA, 2018.

10. Silva EC, Silva MFA, Nogueira RJMC, et al. Growth evaluation and water relations of Erythrina velutina seedlings in response to drought stress. Brazilian Society of Plant Physiology [online]. 2010;22(4):225233.

11. Hetherington AM, Woodward FI. The role of stomata in sensing and driving environmental change. Nature [online]. 2003;524: 901-908.

12. Hsiao TC. Plant responses to water stress. Annual Review of Plant Physiology. 1973;24:519-570.

13. Silva Do, Seifert M, Schiedeck G, et al. Phenological and physicochemical properties of Pereskia aculeata during cultivationin south Brazil. Horticultura Brasileira [online]. 2020;36:325-329.

14. Sajeva M, Mauseth JD. Leaf-like structure in the photosynthetic, succulent stems of cacti. Annals of Botany. 1991;68:405-411.

15. Garcia M, Lapp M, Castro M, Anatomia foliar comparada de cuatro espécies del gênero Pereskia (Plum.) Miller (Cactaceae). Ernstia, 2000;10(1):27-41. 
16. Mcelwain JC, Chaloner WG. Stomatal density and index of fossil plants track atmospheric carbon dioxide in the Paleozoic. Annals of Botany. 1995;76(4):389-395.

17. Reichardt K, Timm LC. Os processos. In: Solo, planta e atmosfera. Conceitos, processos e aplicações. São Paulo: Manole, Barueri, SP, Brazil, 2004;87-145.

18. Brito AS, Libardi PL, Mota JC. Desempenho do tensiômetro com diferentes sistemas de leitura. Revista Brasileira de Ciência do Solo [online]. 2009;33:17-24.

19. Genuchten MT. A closed form equation for predicting the hydraulic conductivity of unsaturated soils. Soil Science Society of American Journal [online]. 1980;44:892-898.

20. Dourado Neto D, Nielsen DR, Hopmans JW, et al. Software to model soil water retention curves (SWRC, versão 2.0). Scientia Agricola [online], Piracibada. 2000;57(1):191-192.

21. Aguiar TV, Sant'anna-Santos BF, Azevedo AA, et al. Software de análises quantitativas para estudos em anatomia vegetal. Planta Daninha[online]. 2007;25(4):649-659.

22. Rhizopoulou S, Psaras G. Development and structure of drought-tolerant leaves of Mediterranean shrub Capparis spinosa L. Annals of Botany [online]. 2003;92(3):377-383.
23. Eggli U. Stomatal types on Cactaceae. Plant Systematics and Evolution. 1984;146:3-4;197-214.

24. Herrera A, Cuberos M. Stomatal size, density and conductance in leaves of some xerophytes from a thorn scrub in Venezuela differing in carbon fixation pathway. Ecotropicos, 1990;3(2):67-76.

25. Klooster B, Palmer-Young E. Water stress marginally increases stomatal density in E. canadensis, but not in A. Gerardii. Tillers[online]. 2004;5:35-40.

26. Changai S, Baod D, Yunzhou Q, et al. Physiological regulation of high transpiration efficiency in winter wheat under drought conditions. Plant Soil Environment[online]. 2012;56(7):340-347.

27. Metcalfe, CR, Chalk L. Anatomy of the dicotyledons: leaves, stem, and wood in relation to taxonomy with notes on economic uses. v. 1. Oxford: Claredon Press, 1950;xi-xvi:698-706.

28. Cutler JM, Rains DW, Loom RS. The importance of cell size in the water relations of plants. Physiologia Plantarum. 1977;40(4):255-260.

29. Taiz L, Zeiger E. Water balance in the plants. In: Fisiologia Vegetal. $3^{\mathrm{a}} \mathrm{Ed}$. Porto Alegre: Artmed, Brasil, 2004;47-65.

30. Queiroz CRAA. Cultivo e composição química de Ora-pro-nóbis (Pereskia aculeata Mill.) sob déficit hídrico intermitente no solo, 2012;144. 